\title{
Ultrasonic assessment and finite element modelling of thermo-mechanical damage in mortar
}

\section{Avaliação ultrassônica e modelagem com elementos finitos do dano termomecânico em argamassa}

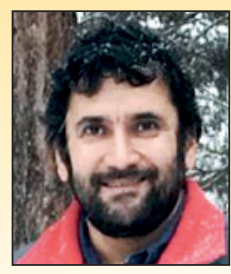

C. L. NOGUEIRA carnot.nogueira@ucdenver.edu

\begin{abstract}
Experiments were conducted to evaluate degradation of mechanical properties in mortar specimens subjected to thermal and mechanical loading. Ultrasonic pulse velocity was used to assess changes in the microstructure of the specimens due to thermal and mechanical loads applied separately. Both longitudinal and transverse waves were used. At first the specimens were tested in the undamaged stage, and then they were also tested after their exposure to a non-uniform thermal load only, finally, mechanical loading was applied until peak load. A finite element model was used in the dynamic simulation of pulses propagation. Results showed that mortar mix with a larger proportion of coarser aggregates is more sensitive to mechanical loading after exposure to heat than mortar with lesser and smaller aggregate contents. Mortar mix design with less and finer aggregate did not show a reduction in the pulse velocity as intense as the mortar with more coarse aggregate, which indicates a less severe diffuse microcracking
\end{abstract}

Keywords: ultrasonic testing of concrete, thermo-mechanical damage, uniaxial compressive loading, finite element modelling, nondestructive testing.

\section{Resumo}

No presente artigo, a degradação das propriedades mecânicas de corpos de prova de argamassas sujeitos a carregamentos térmicos e mecânicos foi avaliada experimentalmente. A velocidade do pulso ultrassônico foi usada para avaliar mudanças na microestrutura dos corpos de prova devido ao carregamento térmico e ao carregamento mecânico separadamente. Pulsos longitudinais e transversais foram usados na avaliação. Inicialmente, foram testados corpos de prova sem qualquer dano; posteriormente, os testes foram repetidos apos a aplicação de um carregamento térmico não uniforme. Na terceira etapa dos testes, os corpos de prova foram avaliados com ultrassom durante a aplicação de carregamento mecânico uniaxial até a ruptura. Uma modelagem numérica com elementos finitos foi usada no estudo da propagação dos pulsos. Os resultados mostraram que o traço de argamassa com maior teor de agregados graudos é mais suscetível ao dano mecânico, após a aplicação do carregamento térmico, que a argamassa com menor teor de agregados e agregados mais finos. A argamassa com menor teor quantidade de agregados e mais fina granulometria não apresentou redução na velocidade do pulso ultrasônico tao intensa quanto a argamassa com agregado mais graúdo, o que indica uma microfissuração menos severa.

Palavras-chave: ensaio ultrassônico para concreto, dano termomecânico, compressão uniaxial, elementos finitos, ensaios não destrutivos.

Dept. of Civil Engineering, Univ. of Colorado Denver, Denver, CO, USA. Dept. of Civil Engineering, Federal University of Pernambuco, Recife, PE, Brazil. 


\section{Introduction}

When subjected to mechanical or thermal loading materials like mortar and concrete undergo severe microcracking and concomitant degradation of their elastic properties. Damage in concrete due to thermal loading alone can be easily characterized, even for temperatures as low as $150^{\circ} \mathrm{C}$, with microscopic imaging, in the form of visible opening around the aggregates $[7,28]$. The openings directly affect the propagation of ultrasonic elastic waves and reduces pulse velocity in the thermally damaged concrete $[6,19,29]$. Mathematical modeling of such form of diffuse damage still challenges the most recent developments of continuum damage mechanics theories and fracture mechanics. As a consequence, for the assessment of damage due to fire in rehabilitation projects the engineer has to rely upon nondestructive evaluation (NDE) techniques.

The most remarkable advantages of NDE techniques when compared to traditional destructive and semi-invasive techniques are: their applicability for in situ inspection of structures and their noninvasive nature [21]. Among the available NDE techniques (radar, schmidt hammer, tomography, thermography, acoustic emission, etc.), the ones based on ultrasonic pulses propagation have proved to be more suitable for the assessment of distributed damage (e.g. microcracking due to thermal-mechanical damage). Because of its relatively low cost and capacity of revealing microscopic changes in the inspected material, ultrasonic testing has been applied to evaluate mechanical [16, 20, 25], thermal [3, 5-8, 10, 12, 28, 29], and environmental [24] damage in concrete. Concrete's intrinsically complex nature has its characteristics depending on many factors, in such a way that theoretical models are of little help in the analysis of concrete performance after exposure to damage. Some complex phenomena associated with diffuse thermal damage, such as post-fire-curing process [29], are not yet completely understood, neither extensively evaluated until now. In this scenario, ultrasonic pulse velocity has been used to evaluate diffuse damage due to fire and to estimate residual compressive strength even in field applications [5, 7]. Traditionally, velocity of ultrasonic pulses traveling through concrete members has been the most reliable parameter used in ultrasonic methods.

In the experiments described in this paper, in order to enhance the understanding of damage processes due to thermal and mechanical loading in cement-based materials, both longitudinal and transverse ultrasonic waves were used to evaluate two mortar mixes with different aggregate proportions of the same type (crushed rock). The variation in the ultrasonic velocity due to thermal loading and due to the application of mechanical load were analyzed experimentally and with a finite element model. Experimental results showed that variations in the ultrasonic pulse speed are greatly influenced by aggregate proportions and size distribution, indicating that these parameters play an important role in the severity of damage when cement-based materials are exposed to the same thermo-mechanical loads.

\subsection{Research significance}

In the last decades, due to concerns with fire-hazard mitigation, several construction codes in different countries have adopted estimates of thermal-load deleterious effects on concrete structural properties, e.g., ABNT-NBR15.200/2012, ACI 216.1-07, ASCE, Eurocode, and CEB [10]. Theoretical evaluation of the residual resistance of concrete subjected to damage as a result of exposure to high temperatures in conjunction with mechanical loading is yet beyond the most recent developments in damage mechanics and fracture mechanics theories. Nonetheless, nondestructive testing with ultrasonic pulses can provide reliable information about
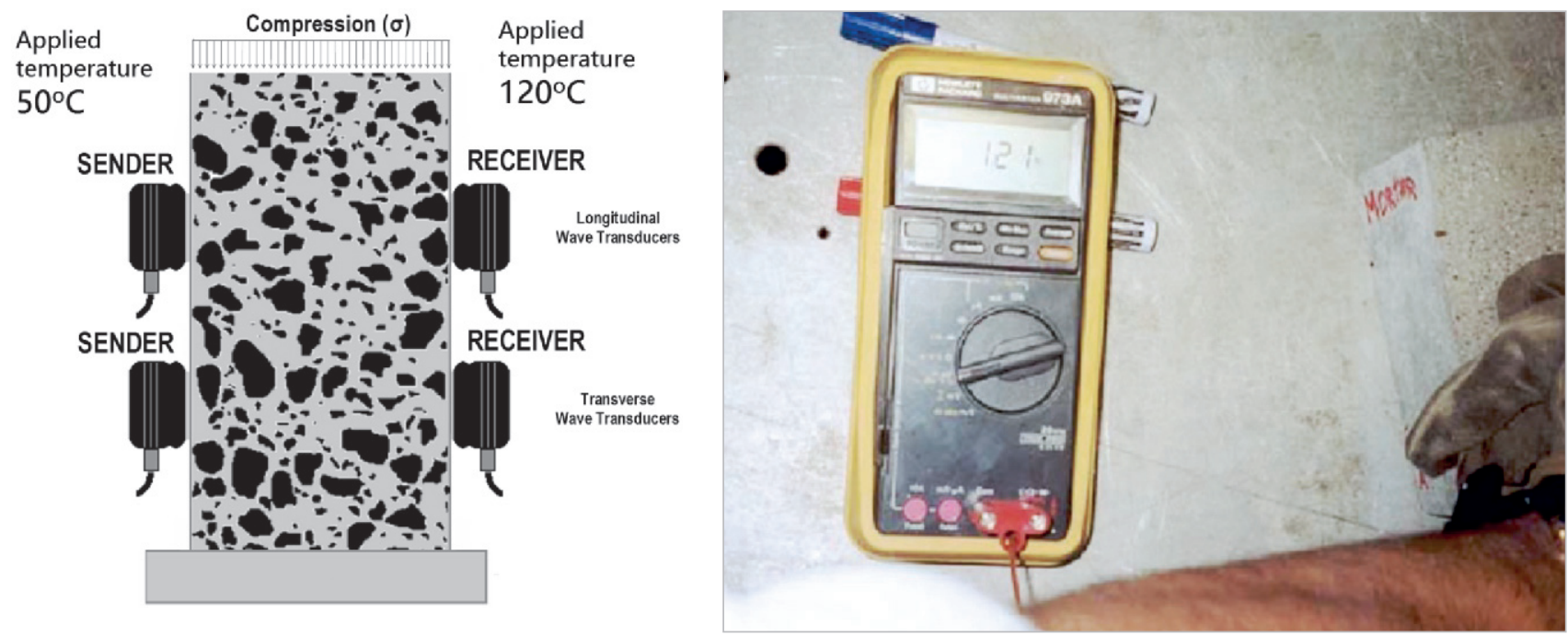

\section{Figure 1}

Schematic representation of the applied thermal loading $\left(50^{\circ} \mathrm{C}\right.$ on the left-hand side and $120^{\circ} \mathrm{C}$ on the right-hand side of the specimen), transducers positions, and compression load (figure on the left). Application of the thermal loading and temperature readings at one of the specimens (photograph on the right) 


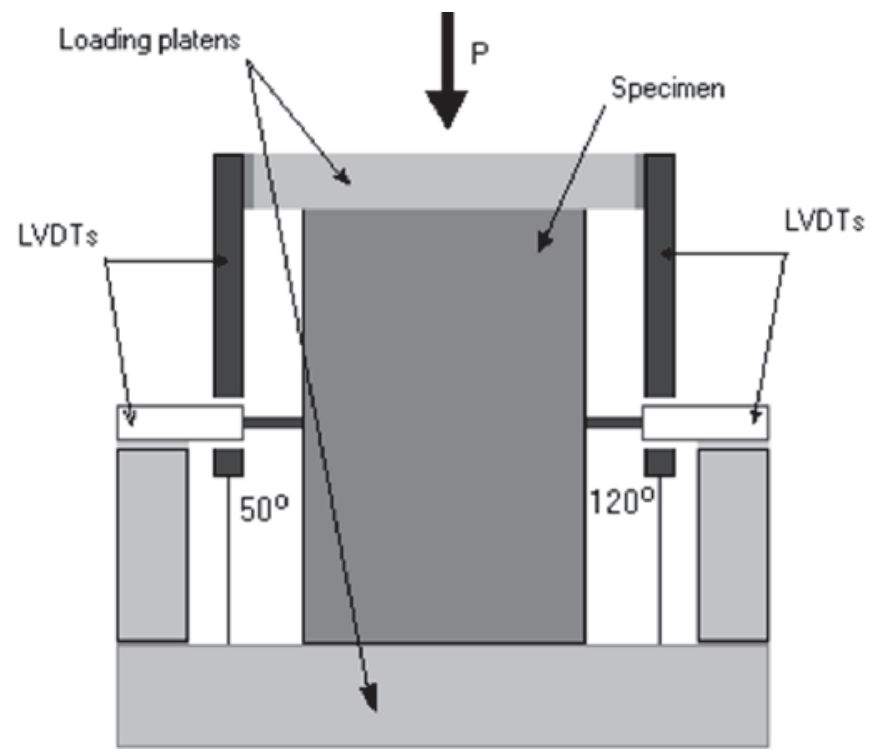

Figure 2

Schematic representation of the position of the loading platens, specimen, LVDTs, and thermal load temperatures

cement-based materials properties regardless of the complexity of the diffuse phenomena that take place during loading (either thermal or mechanical). In addition, a growing demand for reliable nondestructive methods to investigate concrete has taken place in the last decade, mainly because of the need to evaluate damaged concrete structures with diffuse (e.g., environmental, mechanical, thermal damage) or localized damage (cracks, voids, etc.). The objective of the experiments and analysis described in this work is to evaluate the applicability of ultrasonic pulse velocity method (longitudinal and shear waves) in the assessment of thermo-mechanical damage in mortar with different mixes. The experimental program also assesses how aggregate total amount and aggregate size distribution affect damage due to thermal and mechanical loads. The results presented can be used as a reference in the analysis of other cement-based granular materials with fine or coarse aggregates. A finite element model was used to evaluate ultrasonic pulse longitudinal and shear propagation velocities in order to validate the experimental results obtained.

\section{Materials and experimental setup}

Two prismatic mortar specimens (dimensions: $76.2 \times 76.2 \times 152.4$ $\mathrm{mm}, 3 \times 3 \times 6$ in) with different mixes were used in the experiments. Initially, the ultrasonic pulse velocity in the unloaded specimens was measured. Each specimen was then exposed to two heat sources at different temperatures in the two opposite sides until a steady state was reached. The specimens were then exposed to the steady state temperature for one hour and, after cooling, tested with ultrasound pulse velocity. After that, the specimens were uniaxially loaded until failure. During the application of uniaxial load ultrasonic pulses were recorded and - again - analyzed with regard to changes in velocity.

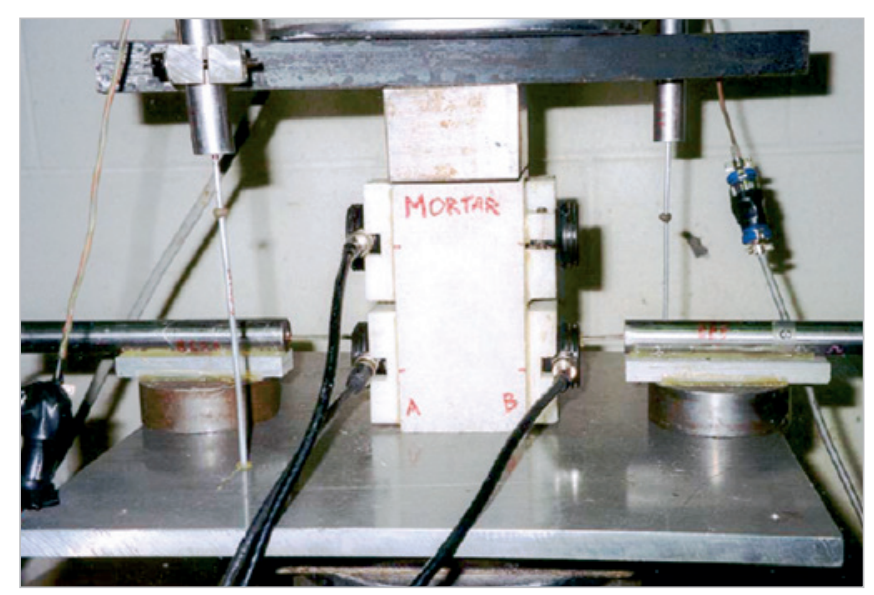

Figure 3

Experimental setup: after a steady state was achieved, side $\mathrm{A}$ had a temperature of $50^{\circ} \mathrm{C}$ and side $\mathrm{B}$ a temperature of $120^{\circ} \mathrm{C}$. The steady state was kept for one hour and then the specimen was cooled down to room temperature for the application of the mechanical loading and ultrasonic tests

\subsection{Testing equipment}

Two heat guns were used in the application of the thermal loading and a digital thermometer was used to read the temperatures on the specimens (Figure 1). A universal MTS loading machine with a maximum capacity of $484 \mathrm{kN}$ (110 kips) was used for the application of the mechanical load in the specimens. Load is measured using internal load cells and calibrated so that the output voltage determines the axial load. External axial and lateral LVDTs (linear variable displacement transducer) were used to measure the deformations on the specimens. Schaevitz model 200 HR-DC LVDTs, with a range of 10.16 $\mathrm{mm}$ (0.4 in) corresponding to an output voltage of $-10 \mathrm{~V}$ to $10 \mathrm{~V}$, were used to measure the axial deformations. For the lateral deformation Schaevitz model 500 HR-DC LVDTs were used: range of $25.4 \mathrm{~mm}$ (1 in) and same output voltage. During the experiments load and LVDTs output were recorded in time intervals of 1 second. Figure 2 schematically shows the position of the loading platens, specimen, and LVDTs. The ultrasonic instrumentation is composed of three parts: the ultrasonic longitudinal and transverse wave transducers, a pulser/receiver card, and an oscilloscope card assembled in the computer that records the output from the pulser/receiver card. Both longitudinal and transverse wave transducers have a diameter of $25.4 \mathrm{~mm}(1.0$ in). The longitudinal wave transducer, which operates at a frequency of $500 \mathrm{kHz}$, and the transverse wave transducer, that operates at $250 \mathrm{kHz}$, were applied according to Figure 1: both pairs were glued along the sides of each specimen, at $1 / 3$ (transverse wave transducers) and 2/3 (longitudinal wave transducers) of the specimen height. All ultrasonic velocity measurements, both in undamaged and damaged specimens, where done according to Figure 1. The transducers provide heavily damped broadband performance, producing improved signal-to-noise in attenuating and scattering materials. In the experiments - Figure 3 - the transducers were firmly attached to the 
specimens using plastic supports glued to their sides, a thin layer of couplant was provided between the transducer surface and the grinded sides of the specimens. The pulser/receiver card allows the user to control gain, high-pass and low-pass filters in order to obtain the cleanest signal possible. The oscilloscope card reads the signal from the pulser receiver and stores it in a file.

\subsection{Test specimens}

Mix proportions of the two specimens used in the experiments are shown on Table 1. Both specimens were prepared with Type 1 Portland cement and kept in the fog room for 28 days until they were tested. The specimens were cast in steel molds and kept in ambient conditions for one day, then were put in the fog room, after being taken from the molds. For the first mortar mix (Table $1-$ Mortar 1) aggregate proportions were distributed in accordance to grading requirements of ASTM Standards (column 3 - aggregate proportions, sieves), the ratio cement : aggregate (fine aggregate only) used was 1:3.60. The second mortar mix - Mortar 2 - has a design with equal weight of cement and aggregate (1:1.00), and aggregate was distributed with $50 \%$ retained in sieve $\# 16$ $(1.18 \mathrm{~mm})$ and $50 \%$ retained in sieve $\# 30(0.60 \mathrm{~mm})$. Mix 1 was designed to represent usual sieve distributions found in mortars and in concretes, while mix 2 , with an unusual distribution and very fine aggregates, was used as a reference to evaluate deleterious effect of standardized aggregate distribution while thermal loading was applied (as aforementioned cracking around coarser aggregates has been reported in microscopic analysis of thermally-damaged concrete [7, 28]). A comparison of the ultrasonic pulse velocities in both mixes, after exposure of specimens to the same thermal and mechanical loads, will then reflect the deleterious cracking effect in the cement paste-aggregates interface due to the use of more and coarser aggregate contents. Compressive strength and pulse velocities for the two mixes (undamaged specimens) are also presented in Table 1. As also shown in Table 1, ultrasonic velocities in Mortar 1 and Mortar 2 are not very different, nonetheless compressive strengths are almost 20\% different (Mortar $2-22.4 \mathrm{MPa}$, Mortar $1-26.7 \mathrm{MPa}$ ).

Specimens were $76.2 \times 76.2 \times 152.4 \mathrm{~mm}(3 \times 3 \times 6$ in) prismatic samples with two opposite faces carefully grinded for the attach- ment of the transducers. On each side a longitudinal and a transverse transducer were positioned precisely aligned with the corresponding transducer on the opposite side. Grinding the specimens also ensured good parallelism of the specimen sides where the transducers were attached. The grinded sides were then exposed to the heat guns until a constant temperature of $50^{\circ} \mathrm{C}$ was reached on the left surface (sender transducer) and a temperature of $120^{\circ} \mathrm{C}$ was attained on the right side (Figure 1 and Figure 3 ). This steady state was kept constant for one hour and a linear variation of temperature was assumed to exist between the opposite sides (for larger specimens and higher temperatures $-600^{\circ} \mathrm{C}-$ a period of 2 hours was proven to be enough to reach steady state [29]). After cooling, the specimens were attached to the LVDTs and transducers and positioned in the loading frame (Figure 3). After application of a small load - approximately $1 \%$ of the maximum load - LVDTs were adjusted to operate in the most accurate region of their calibration curves.

\section{Mechanical behavior of concrete exposed to high temperatures}

When exposed to high temperatures concrete undergoes several phenomena (thermal expansion, drying shrinkage, release of gases, diffusion of water, increase in pore pressure, etc.) that will ultimately lead to a degradation of its elastic properties. This degradation of the mechanical properties of concrete after being exposed to high temperatures is considered to be a consequence of diffuse microcracking [3] which occur mostly around the aggregates [7, 28]. Experimental studies have shown that the modulus of elasticity of concrete decreases with the increase of the temperature according to the following relation [3]:

$\frac{E_{T}}{E_{0}}=\left(1-\frac{T}{T_{0}}\right)^{2}$

here $T_{0}=900^{\circ} \mathrm{C}$.

Figure 4.a show the variation of the modulus of elasticity for concretes with different aggregate types. Poisson's ratio shows a slight increase with temperature up to approximately $50^{\circ} \mathrm{C}$ (Figure 4.b). After that point Poisson's ratio shows a fast decrease in its

\section{Table 1}

Mix proportions and mechanical properties

\begin{tabular}{|c|c|c|c|c|c|}
\hline Designation & $\begin{array}{c}\text { Mix proportions' } \\
\text { C:CA:FA (W/C) }\end{array}$ & $\begin{array}{c}\text { Aggregate } \\
\text { proportions } \\
\text { (sieves) } \\
0.5 \text { " 3/8" \#4 \#8 } \\
\# 16 \# 30\end{array}$ & $\begin{array}{l}\text { Compr. strength }{ }^{3} \\
\left(f_{c k}\right)(\mathrm{MPa})\end{array}$ & $\begin{array}{l}\text { Long. pulse } \\
\text { velocity }{ }^{3}(\mathrm{~m} / \mathrm{s})\end{array}$ & $\begin{array}{c}\text { Transv. pulse vel. }{ }^{3} \\
(\mathrm{~m} / \mathrm{s})\end{array}$ \\
\hline Mortar 1 & $\begin{array}{c}1: 0.00: 3.60 \\
(0.55)\end{array}$ & $\begin{array}{lll}0.00 & 0.00 & 0.18 \\
0.28 & 0.36 & 0.18\end{array}$ & 26.744 & 3898 & 2369 \\
\hline Mortar 2 & $\begin{array}{c}1: 0.00: 1.00 \\
(0.50)\end{array}$ & $\begin{array}{lll}0.00 & 0.00 & 0.00 \\
0.00 & 0.50 & 0.50\end{array}$ & 22.404 & 3850 & 2210 \\
\hline
\end{tabular}




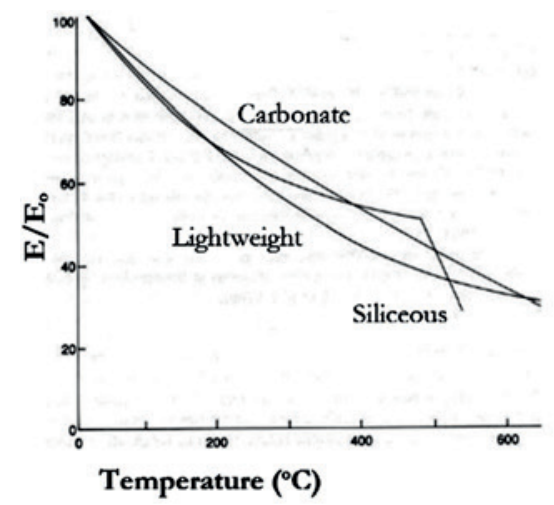

A

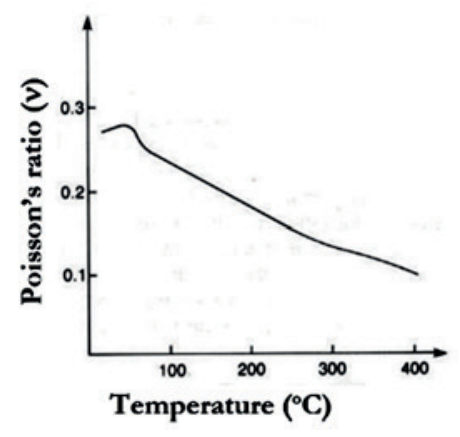

B

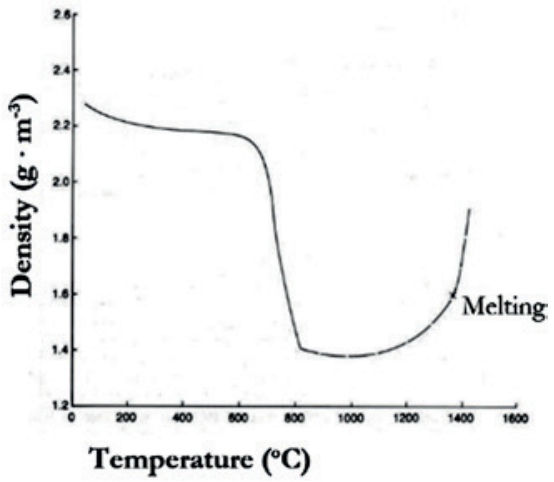

C

\section{Figure 4}

Degradation of cement-based materials properties at high temperatures: (a) Variation of the modulus of elasticity of Portland concretes with various aggregates as a function of the temperature (Cruz, 1966 (4)); (b) Variation of the Poisson's ratio of Portland cement concrete (Marechal, 1972 (15)); (c) Effect of temperature in the density of concrete (Schneider, 1982 (23))

value with the increase in the temperature. Curing conditions are one of the most influential factors in the variation of concrete density with increase in temperature. Concretes cured at $20^{\circ} \mathrm{C}$ with a relative humidity of $65 \%$ are relatively stable with respect to their density up to temperatures of $600^{\circ} \mathrm{C}$ (Figure 4.C). All three factors mentioned above, namely, modulus of elasticity, Poisson's ratio,

\section{Table 2}

Ultrasonic wave velocities measured during the experiments

\begin{tabular}{|c|c|c|c|c|c|}
\hline \multicolumn{3}{|c|}{ Mortar 1} & \multicolumn{3}{|c|}{ Mortar 2} \\
\hline Stage & $\begin{array}{c}\text { Longitudinal } \\
\text { pulse velocity } \\
(\mathrm{m} / \mathrm{s})\end{array}$ & Transverse pulse & Stage & $\begin{array}{l}\text { Longitudinal } \\
\text { pulse velocity } \\
\text { (m/s) }\end{array}$ & Transverse pulse \\
\hline Undamaged' & 3898 & 2369 & Undamaged' & 3850 & 2210 \\
\hline $\begin{array}{l}\text { Thermal } \\
\text { damage }\end{array}$ & 3896 & 2342 & $\begin{array}{l}\text { Thermal } \\
\text { damage }\end{array}$ & 3626 & 2107 \\
\hline $\begin{array}{l}\text { Mechanical } \\
\text { damage } \\
\left(67.45 \%{ }^{3}\right)\end{array}$ & 3588 & 2276 & $\begin{array}{l}\text { Mechanical } \\
\text { damage } \\
\left(86.13 \%{ }^{3}\right)\end{array}$ & 3606 & 2084 \\
\hline $\begin{array}{l}\text { Mechanical } \\
\text { damage } \\
\left(77.01 \%{ }^{3}\right)\end{array}$ & 3459 & 2218 & $\begin{array}{l}\text { Mechanical } \\
\text { damage }^{2} \\
\left(89.27 \%{ }^{3}\right)\end{array}$ & 3595 & 2075 \\
\hline $\begin{array}{l}\text { Mechanical } \\
\text { damage } \\
\left(88.18 \%{ }^{3}\right) \\
\end{array}$ & $(-)$ & 2057 & $\begin{array}{l}\text { Mechanical } \\
\text { damage } \\
\left(93.87 \%{ }^{3}\right)\end{array}$ & 3582 & 2056 \\
\hline $\begin{array}{c}\text { Mechanical } \\
\text { damage } \\
\left(92.67 \%{ }^{3}\right)\end{array}$ & 3275 & $(-)$ & $\begin{array}{l}\text { Mechanical } \\
\text { damage } \\
\left(95.96 \%{ }^{3}\right)\end{array}$ & 3566 & 2041 \\
\hline $\begin{array}{l}\text { Mechanical } \\
\text { damage } \\
\left(98.06 \%{ }^{3}\right)\end{array}$ & 3195 & $(-)$ & $\begin{array}{l}\text { Mechanical } \\
\text { damage }^{2} \\
\left(99.02 \%{ }^{3}\right)\end{array}$ & 3536 & 1995 \\
\hline \multicolumn{6}{|c|}{$\begin{array}{l}\text { I Undamaged stage, i.e. before exposed to heat or mechanical load; } \\
2 \text { Mechanical load after the exposure to heat; } \\
3 \text { Percentages of the peak load; } \\
\text { (-)Values not available. }\end{array}$} \\
\hline
\end{tabular}


and density, are influential in the pulse propagation velocity. From linear isotropic elasticity, the longitudinal and transverse velocity can be calculated from:

$c_{\text {long }}^{2}=\frac{E_{0}\left(1-v_{0}\right)}{\rho_{0}\left(1+v_{0}\right)\left(1-2 v_{0}\right)}$

$c_{\text {trans }}^{2}=\frac{E_{0}}{\rho_{0}(2)\left(1+v_{0}\right)}$

where $E_{0}, \rho_{0}$, and $v_{0}$ are the values of the modulus of elasticity, the density, and the apparent Poisson's ratio, respectively, of the initial unloaded stage. Therefore, through equations 2.a and 2.b, pulse velocity measurements are very well suited for monitoring diffuse damage in concrete due to exposure to high temperature. In addition, velocity measurements can be also used in the formulation of mechanical damage indicators [16]. It is important to emphasize that velocity measurements based on through-transmission ultrasonic applications (the pulse crosses the specimens from one side - sender transducer - to the other - receiver transducer; Figure 4) are not only very reliable and repeatable (pulses can be easily applied several times), but also easily and promptly applicable to most existing structures. For these reasons, this type of ultrasonic application has been successfully used to assess damage in structures exposed to fire [3, 5, 8], to assess other kinds of diffuse damage $[16,24,25]$, and can even be applied to evalu- ate and characterize concretes [14, 27] and to estimate grain-size distribution in cement-based materials [17, 18]. Other techniques to assess thermal damage, based on nonlinear ultrasound and resonance have been so far applied to small samples [19, 28, 29]; unfortunately extraction of samples implies not only damage to the real structures, but also damage and perturbation of the extracted portion (unload, stress release, cracks, etc.), for this reason, ultrasonic testing based on through-transmission techniques are more adequate for assessing fire-damaged concrete.

\section{Experimental results}

Transverse and longitudinal digital signals were recorded at three stages: (1) undamaged specimen - before the application of thermal loading; (2) after the application of thermal loading; and (3) during the application of the mechanical loading - in the nonlinear part of the concrete loading curve, i.e., after approximately $70 \%$ of the maximum load until peak load. In order to improve the signalto-noise ratio, the signals were averaged.

In the experiments, the increase in the lateral dimensions of the specimens, due to Poisson's effect, was taken into account in the velocity measurements. The travel time was determined as the difference between (a) the zero-crossing of the ultrasonic pulse recorded with the transmitting and receiving transducers glued together with a thin layer of couplant, and (b) the pulse recorded after attaching the transducers to the specimen sides - then the

Table 3

Ultrasonic wave velocities decrease

\begin{tabular}{|c|c|c|c|c|c|}
\hline \multicolumn{3}{|c|}{ Mortar 1} & \multicolumn{3}{|c|}{ Mortar 2} \\
\hline Stage & $\begin{array}{l}\text { Longitudinal } \\
\text { pulse velocity } \\
\text { decrease }^{1}\end{array}$ & $\begin{array}{c}\text { Transverse pulse } \\
\text { velocity } \\
\text { decrease }^{1}\end{array}$ & Stage & $\begin{array}{l}\text { Longitudinal } \\
\text { pulse velocity } \\
\text { decrease' }^{1}\end{array}$ & $\begin{array}{l}\text { Transverse pulse } \\
\text { velocity decrease }\end{array}$ \\
\hline $\begin{array}{l}\text { Thermal } \\
\text { damage }\end{array}$ & -0.05 & -1.14 & $\begin{array}{l}\text { Thermal } \\
\text { damage }\end{array}$ & -5.82 & -4.66 \\
\hline $\begin{array}{c}\text { Mechanical } \\
\text { damage } \\
\left(67.45 \%{ }^{3}\right)\end{array}$ & -7.95 & -3.92 & $\begin{array}{c}\text { Mechanical } \\
\text { damage } \\
\left(86.13 \%^{3}\right) \\
\end{array}$ & -6.34 & -5.70 \\
\hline $\begin{array}{c}\text { Mechanical } \\
\text { damage } \\
\left(77.01 \%{ }^{3}\right) \\
\end{array}$ & -11.26 & -6.37 & $\begin{array}{c}\text { Mechanical } \\
\text { damage2 } \\
(89.27 \% 3) \\
\end{array}$ & -6.62 & -6.11 \\
\hline $\begin{array}{c}\text { Mechanical } \\
\text { damage } \\
\left(88.18 \%{ }^{3}\right)\end{array}$ & $(-)$ & -13.17 & $\begin{array}{c}\text { Mechanical } \\
\text { damage } \\
\left(93.87 \%^{3}\right)\end{array}$ & -6.96 & -6.97 \\
\hline $\begin{array}{c}\text { Mechanical } \\
\text { damage } \\
\left(92.67 \%{ }^{3}\right)\end{array}$ & -15.98 & $(-)$ & $\begin{array}{c}\text { Mechanical } \\
\text { damage } \\
\left(95.96 \%^{3}\right)\end{array}$ & -7.38 & -7.65 \\
\hline $\begin{array}{c}\text { Mechanical } \\
\text { damage } \\
\left(98.06 \%{ }^{3}\right)\end{array}$ & -18.03 & $(-)$ & $\begin{array}{c}\text { Mechanical } \\
\text { damage } \\
\left(99.02 \%{ }^{3}\right)\end{array}$ & -8.16 & -9.73 \\
\hline \multicolumn{6}{|c|}{$\begin{array}{l}\text { 1 Percentage with respect to the pulse velocity on the undamaged specimen; } \\
2 \text { Mechanical load after the exposure to heat; } \\
3 \text { Percentages of the peak load; } \\
\text { (-) Values not available. }\end{array}$} \\
\hline
\end{tabular}


pulse propagates through the concrete specimens (as shown in the left-hand side of Figure 1 in this article). A schematic representation of time measurements can be found on figure 1 of Nogueira, 2011 [18]. This procedure leads to more accurate measurements because delays that occur as a consequence of the experimental setup characteristics (e.g., length of the cables, thickness of the couplant layer, etc.) are accounted for in the measurement of the transducer-transducer zero-crossing.

Values of longitudinal and transverse velocities measured during the experiments are summarized on Table 2, some of the velocity measurements were not recorded due to partial detachment of the transducers while compression was applied. Relative variation of the velocities - using undamaged state as reference - is shown on Table 3. It can be observed from Table 3 that the variation of the pulse velocity in Mortar 1 specimen (for both longitudinal and transverse waves) shows only a small decrease due to thermal loading: approximately $1 \%$ decrease for the shear wave, and $0.05 \%$ for the longitudinal wave - while the decrease in velocity in Mortar 2 specimen due to thermal loading is about $5 \%$ for both pulses. Although apparently a paradox, the formation of more cracks in Mortar 1 (that has more and coarser aggregates) along the interfaces cement paste-aggregates due to thermal load [28] can lead to the reduction of the acoustical mismatch around the aggregates - which results in an increase in both pulse amplitudes and pulse velocities [16]. On the other hand, with the application of mechanical load, Mortar 1 shows a consistent decrease in velocity measurements until almost $20 \%$, while the decrease in Mortar 2 specimen is smaller than $10 \%$ (although the stress-strength ratio for the Mortar 2 specimen is only a little higher than the ratio for the Mortar 1). This more accentuated decay in the pulse velocities in the Mortar 1 specimen can be associated with the increase in microcrack openings around the aggregates now due to mechanical loading.

Degradation of elastic properties leading to velocity decay - equation 2 - is more intense in Mortar 1 because more and bigger microcracks develop around the aggregate phase while load is applied. Mortar 2 - which has less and finer aggregates - showed approximately half of the velocity decay when compared with Mortar 1 . For the longitudinal pulse, at $98 \%$ of maximum load, Mortar 1 showed a velocity reduction of $18.03 \%$, while in Mortar 2, at $99 \%$ of maximum load, reduction was only $8.16 \%$. Similarly, for the transverse pulse, at $88 \%$ of maximum load velocity reduction was $13.17 \%$ for Mortar 1 , while at $93 \%$ of peak load reached only $6.97 \%$ for Mortar 2. It is important to emphasize that at approximately $95 \%$ of the peak load the visible cracks appeared in both specimens.

This more accentuated decay in pulse propagation velocity in the Mortar 1 specimen can be explained by the fact that this mix leads to a more heterogeneous material, with bigger inclusions (coarser aggregate). As a consequence, while exposure to heat only does not lead to a more accentuated damage in form of microcracks, the application of mechanical load after heating further induce microcrack formation and growth, leading to the degradation of elastic parameters and reducing both longitudinal and transverse wave velocities (equations 2 show the relation between elastic parameters and ultrasonic velocities). This leads to the following conclusion: coarser mixes and mixes with more aggregates - such as Mortar 1 - are more vulnerable to mechanical load after thermal exposure than finer mixes (such as Mortar 2). After being subjected to
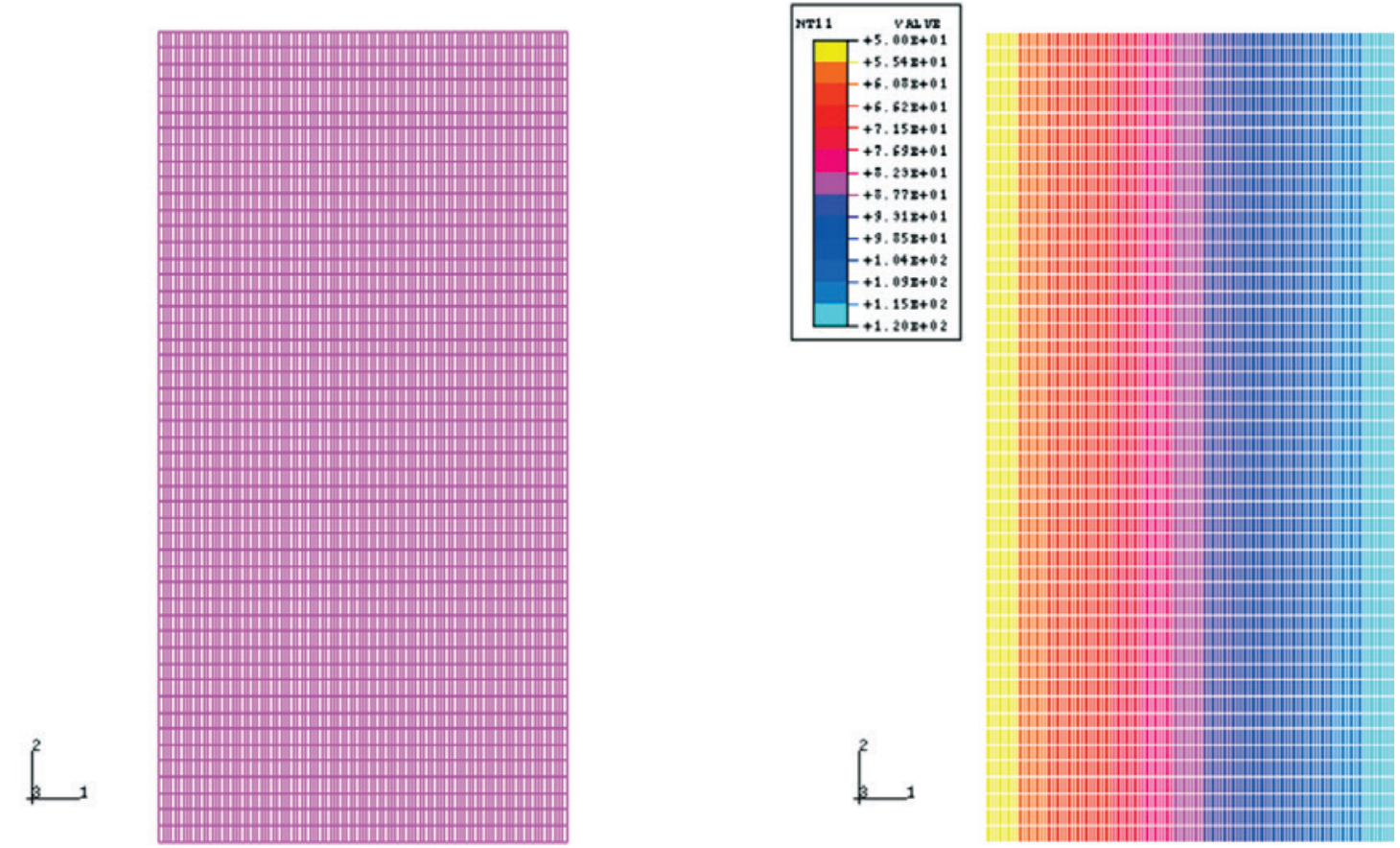

\section{Figure 5}

Finite element model (5151 nodes, 5000 elements) and temperature variation in the wave propagation direction 
thermal loading Mortar 2 experienced a much less severe reduction in its structural capacity than Mortar 1 did, indicating that the elastic parameters degraded much more in coarser mixes. It can be concluded that - after exposed to fire and heat - concrete structures with coarser aggregates will be much more sensitive to mechanical load application. This interesting result is certainly useful in mitigating the consequences of fire-exposure in real structures and can also help developing strategies to help reduce deleterious effects of heat in concrete structures.

\section{Finite element model}

A finite element model (FEM) was used in the analyses of the experimental results. The model, with a total of 5151 nodes and 5000 four-node plane strain elements, was implemented using ABAQUS software. The mesh and the linear temperature variation along the wave propagation direction are shown on Figure 5. For a more precise representation of the displacements transmitted by the transducers on the surface of the specimen the transducer-transducer pulses were approximated by a Fourier series:

$u(t)=A_{0}+\sum_{n=1}^{N}\left[A_{n} \cos (n \cdot w \cdot t)+B_{n} \sin (n \cdot w \cdot t)\right]$

here, a total of 101 coefficients $(\mathrm{N}=50)$ was calculated using a nonlinear data-fitting routine. The signal digitally recorded and the Fourier approximation (almost coincident) are shown on Figure 6. In the dynamic analysis ABAQUS uses an implicit dynamic integration scheme with controllable numerical damping based on the a-method by Hilber and Hughes [1, 9]. This method has several advantages when compared with the Houbolt and collocation point methods (these methods affect the low modes too strongly). The a-method is also more efficient than Wilson method collocation schemes because these two methods have pathological displacement overshot characteristics [9].

In the analysis, the values modulus of elasticity and Poisson's ratio, and the density of the mechanically damaged specimens were assumed to vary (degrade) according to the experimental data available (Figure 4). Therefore, mechanical degradation, which manifests itself as a decrease in the elastic modulus and Poisson's ratio, as well as through the changes in the density, due to the thermal load were taken into account. For the thermal degradation of the mechanically damaged values the following assumptions were made (based on experimental results): (1) Elastic modulus was assumed to decrease according to Equation 1; (2) Poisson's ratio was assumed to vary according to Figure 4.b; and (3) Density was assumed to decrease according to Figure 4.c. Therefore, for each node temperature, thermal degradation of each property was considered and the temperatures were assumed to vary as shown in Figure 5.

In order to more accurately model the experiments, longitudinal and transverse waves were simultaneously applied at the corresponding nodes in the mesh (in the experiments the transducers displacements are applied simultaneously). The displacements of the transverse and longitudinal waves during their propagation can be observed in Figure 7.

Velocities in the model were measured in the same fashion as in the experiments: travel times were taken as the difference

\section{Longitudinal wave}

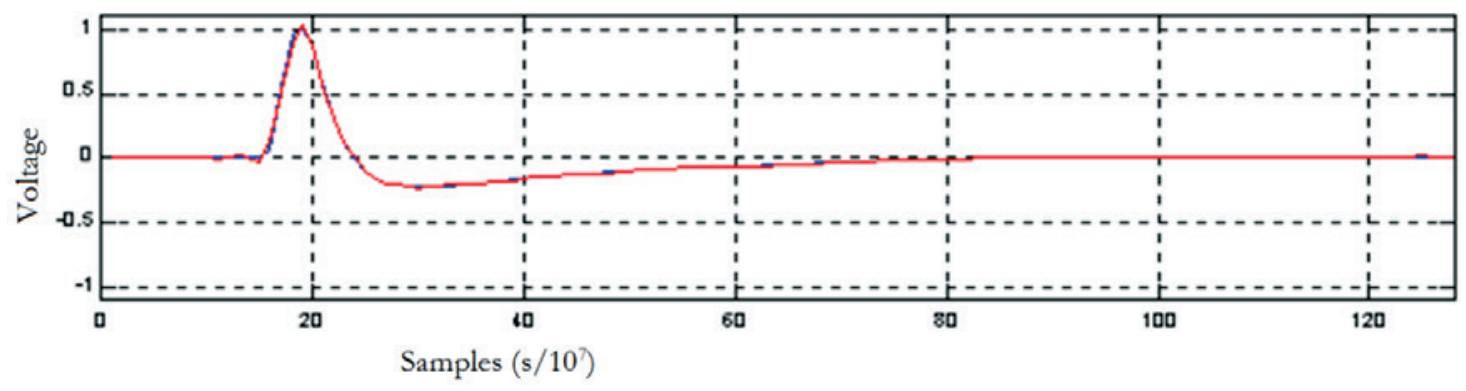

Transverse wave

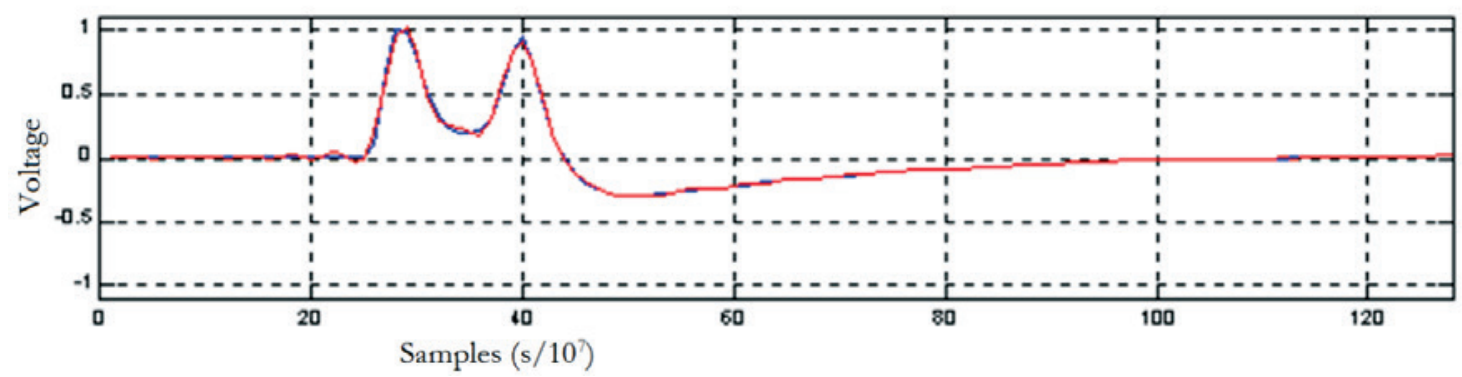

Figure 6

Longitudinal and transverse waves: Fourier series approximation (red) and signals digitally recorded (blue - partially hidden by the Fourier approximation) are almost coincident 

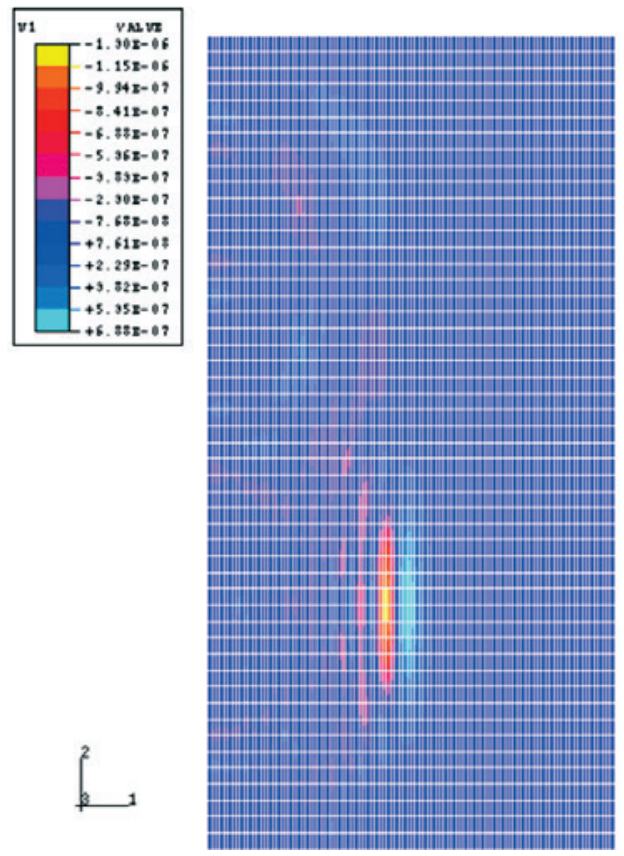
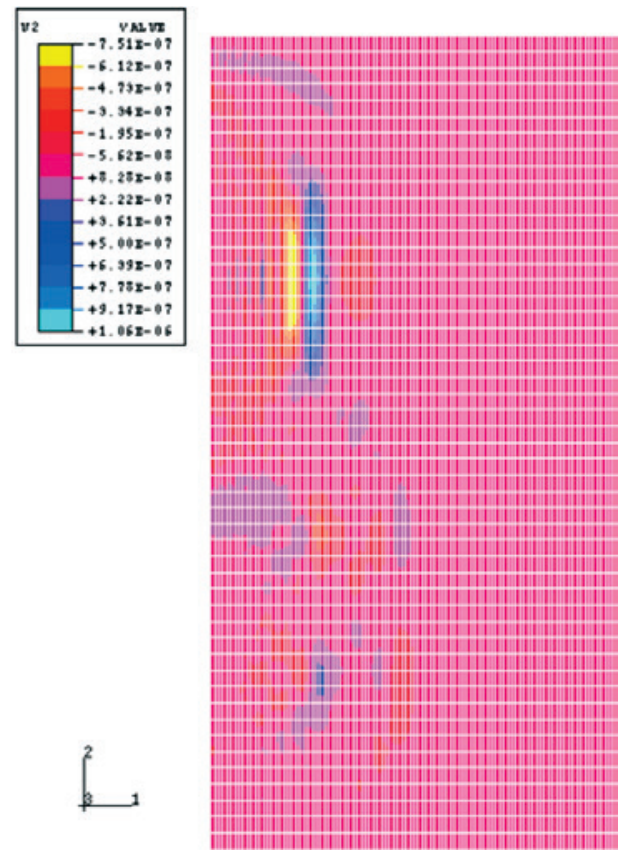

\section{Figure 7}

Displacements corresponding to the longitudinal (left, displacement U1) and transverse wave (right, displacement U2) propagation through the specimen

between the zero-crossings of the transmitted and received waves. Displacements of some representative nodes in the FEM are shown in Figure 8. In the figure, displacements corresponding to the propagation of the transverse wave and longitudinal wave along the centers of the transmitting and receiving transducers are represented; lines S1 and L1 correspond to the transmitted wave (center of transmitter transducers), S2 and L2 corresponds to a point in the middle of the pulse path, and S3 and L3 correspond to the node at the center of the receiver transducer. As shown on Table 4, the values of the velocities calculated using the finite ele-

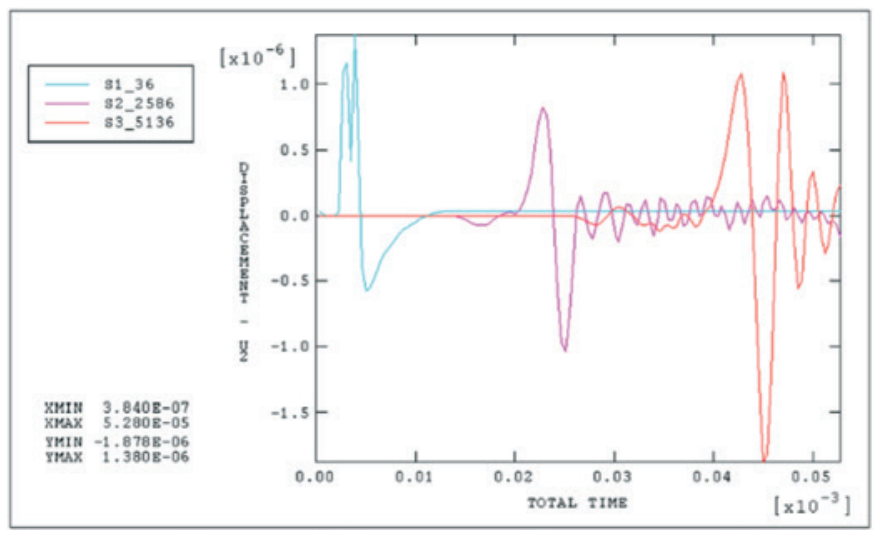

ment model are lower than the values from the experiments. The variation of the velocities with respect to the undamaged reference values is presented on Table 5. Velocities decay computed using the finite element model was not consistent with the experimental results. Mortar 2 showed a higher sensitivity to thermal damage than Mortar 1, contradicting the experimental results. This inconsistency in the results may be a consequence of some limitations of the model used in the analysis - basically, the model used does not take into account microcrack formation and development due to loading. In addition, due to the relatively short exposure to the

\section{Figure 8}

Displacements corresponding to the propagation of transverse (left-had side) and longitudinal (right-had side) waves along the centers of the transmitting and receiving transducers. Signals S1 and L1 correspond to the transmitted wave (center of transmitting transducer), S2 and L2 correspond to a point in the middle of pulse path, S3 and L3 correspond to the node at the center of the receiver transducer 


\section{Table 4}

Ultrasonic wave velocities calculated in the finite element model

\begin{tabular}{|c|c|c|c|c|c|}
\hline \multicolumn{3}{|c|}{ Mortar 1} & \multicolumn{3}{|c|}{ Mortar 2} \\
\hline Stage & $\begin{array}{l}\text { Longitudinal } \\
\text { pulse velocity } \\
(\mathrm{m} / \mathrm{s})\end{array}$ & $\begin{array}{l}\text { Transverse pulse } \\
\text { velocity }(\mathrm{m} / \mathrm{s})\end{array}$ & Stage & $\begin{array}{l}\text { Longitudinal } \\
\text { pulse velocity } \\
\text { (m/s) }\end{array}$ & $\begin{array}{c}\text { Transverse pulse } \\
\text { velocity }(\mathrm{m} / \mathrm{s})\end{array}$ \\
\hline Undamaged ${ }^{1}$ & 3333.81 & 1997.44 & Undamaged' & 3924.75 & 2169.49 \\
\hline $\begin{array}{l}\text { Mechanical } \\
\text { damage } \\
\left(67.45 \%^{3}\right)\end{array}$ & 2968.37 & 1844.63 & $\begin{array}{l}\text { Mechanical } \\
\text { damage } \\
(86.13 \% 3)\end{array}$ & 3389.64 & 1972.82 \\
\hline $\begin{array}{c}\text { Mechanical } \\
\text { damage } \\
\left(77.01 \%{ }^{3}\right)\end{array}$ & 2976.94 & 1845.51 & $\begin{array}{l}\text { Mechanical } \\
\text { damage } \\
\left(89.27 \%{ }^{3}\right)\end{array}$ & 3301.34 & 1967.45 \\
\hline $\begin{array}{c}\text { Mechanical } \\
\text { damage } \\
\left(88.18 \%^{3}\right) \\
\end{array}$ & 2875.45 & 1823.24 & $\begin{array}{l}\text { Mechanical } \\
\text { damage }^{2} \\
\left(93.87 \% \%^{3}\right)\end{array}$ & 3229.48 & 1928.41 \\
\hline $\begin{array}{l}\text { Mechanical } \\
\text { damage } \\
\left(92.67 \%^{3}\right) \\
\end{array}$ & 2836.16 & 1828.32 & $\begin{array}{c}\text { Mechanical } \\
\text { damage }^{2} \\
\left(95.96 \% \%^{3}\right)\end{array}$ & 3166.89 & 1913.12 \\
\hline $\begin{array}{l}\text { Mechanical } \\
\text { damage }^{2} \\
\left(98.06 \%^{3}\right)\end{array}$ & 2778.83 & 1815.14 & $\begin{array}{l}\text { Mechanical } \\
\text { damage } \\
\left(99.02 \%{ }^{3}\right)\end{array}$ & 3005.24 & 1880.39 \\
\hline
\end{tabular}

\section{Table 5}

Ultrasonic wave velocities decrease calculated using the finite element model

\begin{tabular}{|c|c|c|c|c|c|}
\hline \multicolumn{3}{|c|}{ Mortar 1} & \multicolumn{3}{|c|}{ Mortar 2} \\
\hline Stage & $\begin{array}{l}\text { Longitudinal } \\
\text { pulse velocity } \\
\text { decrease' }^{1}\end{array}$ & $\begin{array}{c}\text { Transverse pulse } \\
\text { velocity } \\
\text { decrease }^{1}\end{array}$ & Stage & $\begin{array}{l}\text { Longitudinal } \\
\text { pulse velocity } \\
\text { decrease }^{1}\end{array}$ & $\begin{array}{c}\text { Transverse pulse } \\
\text { velocity decrease }\end{array}$ \\
\hline $\begin{array}{l}\text { Mechanical } \\
\text { damage } \\
(67.45 \% 3)\end{array}$ & -10.96 & -7.65 & $\begin{array}{c}\text { Mechanical } \\
\text { damage } \\
\left(86.13 \%{ }^{3}\right)\end{array}$ & -13.63 & -9.07 \\
\hline $\begin{array}{l}\text { Mechanical } \\
\text { damage } \\
(77.01 \% 3)\end{array}$ & -10.70 & -7.61 & $\begin{array}{c}\text { Mechanical } \\
\text { damage } \\
\left(89.27 \%{ }^{3}\right) \\
\end{array}$ & -15.88 & -9.31 \\
\hline $\begin{array}{l}\text { Mechanical } \\
\text { damage }^{2} \\
\left(88.18 \%^{3}\right)\end{array}$ & -13.75 & -8.72 & $\begin{array}{c}\text { Mechanical } \\
\text { damage } \\
\left(93.87 \%{ }^{3}\right)\end{array}$ & -17.72 & -11.11 \\
\hline $\begin{array}{l}\text { Mechanical } \\
\text { damage } \\
(92.67 \% 3) \\
\end{array}$ & -14.93 & -8.47 & $\begin{array}{c}\text { Mechanical } \\
\text { damage } \\
\left(95.96 \%{ }^{3}\right)\end{array}$ & -19.31 & -11.82 \\
\hline $\begin{array}{l}\text { Mechanical } \\
\text { damage }^{2} \\
\left(98.06 \%^{3}\right)\end{array}$ & -16.65 & -9.13 & $\begin{array}{l}\text { Mechanical } \\
\text { damage } \\
\left(99.02 \%{ }^{3}\right)\end{array}$ & -23.43 & -13.33 \\
\hline
\end{tabular}


thermal loading - only one hour - mechanical properties probably did not degrade according to the assumptions of the model (Figure 4). Bazant and Kaplan [2] call the attention for the disagreement among the results obtained for the variation of the modulus of elasticity from different tests (Bazant and Kaplan, [2], p. 124). The same researchers emphasize that the variation of the Poisson's ratio under thermal loading - this variation is primarily attributed to cracking - is greatly affected by the existence of confining pressure. In the experiments, the application of the mechanical loading may lead to a healing of the degraded Poisson's ratio [2].

With respect to the limitations of the finite element model, some points need to be emphasized: (1) the model cannot capture the effects of important phenomena that affect the ultrasonic pulse propagation (e.g., microcrack onset and development, ultrasonic attenuation, scattering); (2) modeling of the metallic surface of the transducers and the transition region with the couplants was not implemented - displacements were imposed by applying movement to the nodes were the transducers were fixed; (3) non-uniform distribution of the axial load due to the residual thermal expansion of the specimens was not accounted for; and (4) acoustoelastic effect due to specimen compression on ultrasonic wave propagation was also not taken into account. Various phenomena associated with scattering and absorption of the mechanical energy of the propagating pulses that are associated with the granular structure of the specimens and with the diffuse microcracks were not modeled. As a consequence, pulse attenuation - which can result in a slight decrease in the velocity (because attenuation can move the zero-crossing to a forward position in the time domain) - was not evaluated. The modeling of the receiving transducer surface that is attached to the specimen with the couplant would lead to much smaller displacements of the arriving pulse. At that point, instead of hitting a free surface, the pulse would be restrained by the presence of a stiffer material, namely: the metallic surface of the receiving transducer. The non-uniformity of the applied axial load due to the residual thermal strains leads to a non-uniform crack distribution. This effect was assumed to be mitigated by the rotation of the top loading platen on the MTS machine.

\section{Conclusions}

Experiments were conducted to evaluate thermal and mechanical degradation in mortar mixes with different aggregate contents. Ultrasonic testing with both longitudinal and transverse pulses showed that after applying a temperature gradient to the specimens, the mix with more and coarser aggregates is less sensitive to ultrasonic velocity decay. Nonetheless, measurements taken after applying both thermal and mechanical loads (uniaxial compression) showed that the coarser mix is much more sensitive to ultrasonic pulse velocity decay than the mix with finer aggregate. The results clearly proved a much more accentuated degradation of elastic properties in the coarser mix after thermal load was applied. It can be concluded that - after exposed to heating - structures built with cement-based materials with coarser aggregates will be much more sensitive to the application of mechanical loads. This interesting conclusion is certainly useful in mitigating the consequences fire-exposure in real structures and can also help developing strategies to help reduce deleterious effects of heat in concrete structures. With regard to the finite element model used to evaluate the experiments, some limitations could be observed: a more refined model would be necessary to capture basic phenomena in ultrasonic wave propagation (e.g., acoustoelastic effect, scattering and attenuation due to cracks), and a model that captures the onset and propagation of cracks around the aggregates would have to be implemented in order to obtain more consistent FEM results. Besides, more reliable data about the variation of the mechanical properties due to short exposure to thermal loading would also needed to be obtained. Unfortunately, the variation of the mechanical properties with heating depends upon so many factors (curing conditions, aggregate type, rate of temperature increase, water/cement ratio, etc.) it would be necessary a much more sophisticated FEM model to account for all the relevant variables.

\section{Acknowledgements}

The author wishes to thank the University of Colorado Denver College of Engineering and Applied Sciences and Dr. Kevin Rens, Professor and Chair of the Civil Engineering Department, for their continued support.

\section{References}

[1] ABAQUS, Abaqus Theory Manual, Version 5.5, Hibbitt, Karlsson \& Sorensen, inc., 1995.

[2] BAZANT, Z. P., and KAPLAN, M. F., Concrete at High Temperatures: Material Properties and Mathematical Models, Longman Group Limited, 1996.

[3] BENEDETTI, A, On the Ultrasonic Pulse Propagation into Fire Damaged Concrete, ACI Structural Journal, V. 95, No. 3, pp. 259-271, 1998.

[4] CRUZ, C. R., Elastic Properties of Concrete at High Temperature, PCA Bulletin 191, 1966.

[5] DILEK, U., Ultrasonic Pulse Velocity in Nondestructive Evaluation of Low Quality and Damaged Concrete, Journal of Performance of Constructed Facilities, Vol. 21, N. 5, pp. 337344, USA, 2007.

[6] EPASTO, G., PROVERBIO, E., and VENTURI, V., Evaluation of fire-damaged concrete using impact-echo method, Materials and Structures, January 2010, 43:235.

[7] GEORGALI, B., and TSAKIRIDIS, P. E., Microstructure of fire-damaged concrete. A case study, Cement and Concrete composites, 27(2), pp 255-259, 2003.

[8] GHANDEHARI, M., BEHNOOD, A., and KHANZADI, M., Residual Mechanical Properties of High-Strength Concretes after Exposure to Elevated Temperatures, J. Mater. Civ. Eng., 0899-1561(2010) 22: 1(59), 59-64, 2010.

[9] HILBER, H. M., and HUGHES, T. J. R., Collocation, Dissipation and 'Overshoot' for Time Integration Schemes in Structural Dynamics, Earthquake Engineering and Structural Dynamics, Vol. 6, pp. 99-117, 1978.

[10] KNAACK, A. M., KURAMA, Y. C., and KIRKNER, D. J., Compressive Stress-Strain Relationships for North American Concrete under Elevated Temperatures, ACI Materials Journal, V. 107, No. 2, pp. 164-175, 2010. 
[11] LEE, J., XI, Y., AND WILLAM, K., Properties of Concrete after High-Temperature Heating and Cooling, ACI Materials Journal, V. 105, No. 4, pp. 334-341, 2008.

[12] LIMA, R. C. A., HAESBAERT, F. M., CAETANO, L. F., BERGMANN, C. P., and FILHO, L. C. P. S., Microstructural Changes in High Density Concretes Exposed to High Temperatures, IBRACON Materials Journal, Vol. 1, N. 1, pp. 7-14, 2005.

[13] MACHADO, M. D., THELANDERSSON, S., Modeling of Combined Thermal and Mechanical Action in Concrete, Journal of Engineering Mechanics, Vol. 113, No. 6, pp. 893906, 1987.

[14] MACHADO, M.D., SHEHATA, L. C. D., and SHEHATA, I. A. E. M, Correlation Curves to Characterize Concretes Used in Rio de Janeiro by Means of Non-destructive Tests, IBRACON Structures and Materials Journal, Vol. 2, N. 2, pp. 100123, 2009.

[15] MARECHAL, J. C., Variations of the Modulus of Elasticity and Poisson's Ratio with Temperature, Concrete for Nuclear Reactors, ACI SP-34, Vol. 1, pp. 495-503, 1972.

[16] NOGUEIRA, C. L., and WILLAM, K. J., Ultrasonic Investigation of Damage in Concrete Under Uniaxial Compression, ACI Materials Journal, V. 98, No. 3, pp. 265-275, 2001.

[17] NOGUEIRA, C. L., Wavelet Analysis of Ultrasonic Pulses in Cement-Based Materials, ACI Materials Journal, May-June, 2010.

[18] NOGUEIRA, C. L., Wavelet-based analysis of ultrasonic longitudinal and transverse pulses in cement-based materials, Cement and Concrete Research, Vo. 41, pp. 1185-1195, 2011.

[19] PARK, S. J., YIM, H. J., AND KWAK, H. G., Nonlinear resonance vibration method to estimate the damage level on heat-exposed concrete, Fire Safety Journal 69, pp. 36-42, 2014.

[20] RADAKOVIC-GUZINA, Z., Ultrasonic Assessment of Damage in Concrete Under Axial Loads, Ph.D. Thesis, University of Colorado, Boulder, 1997.

[21] Rens, K. L., Nogueira, C. L., Transue, D. J., Bridge Management and Nondestructive Evaluation, Journal of Performance of Constructed Facilities, Vol. 19, N. 1, pp. 3-16, EUA, February, 2005.

[22] ROSTASY, F. S., and BUDELMANN, H., Strength and Deformation of concrete with Variable Content of Moisture at Elevated Temperature up to $90 \mathrm{oC}$, Cement and Concrete Research, Vol. 16, pp. 353-362, 1986.

[23] SCHNEIDER, U., Behavior of Concrete at High Temperatures, Report to RILEM Committee 44-PHT, 1982.

[24] SELLECK, S. F., LANDIS, E. N, PETERSON, M. L., SHAH, S. P., and ACHENBACH, J. G., Ultrasonic Investigation of Concrete with Distributed Damage, ACI Materials Journal, V. 95, No. 1, 1998, pp. 27-36.

[25] SUARIS, W., and FERNANDO, V., Ultrasonic Pulse Attenuation as a Measure of Damage Growth during Cyclic Loading of Concrete, ACI Materials Journal, V. 84, No. 3, 1987, pp. 185-193.

[26] THELANDERSSON, S., Modeling of Combined Thermal and Mechanical Action in Concrete, Journal of Engineering Mechanics, Vol. 113, No. 6, pp. 893-906, 1987.
[27] TORALES-CARBONARI, B. M., CAVALARO, S. H., CASTANHA, J. C. M., GUACELLI, P. A. G., and SILVA, c. c., Utilization of the Ultrasonic Method to Evaluate the Properties of High Performance Concrete, IBRACON Structures and Materials Journal, Vol. 3, N. 4, pp. 494 - 511, 2010.

[28] YIM, H. J., KIM, J. H., PARK, S. P., and KWAK, H. G., Characterization of Thermally Damaged Concrete Using a Nonlinear Ultrasonic Method, Cement and Concrete Research 42 (11), 1438-1446, 2012.

[29] YIM, H. J., PARK, S. P., KIM, J. H., and KWAK, H. G., Nonlinear Ultrasonic Method to Evaluate Residual Mechanical Properties of Thermally Damaged Concrete, ACI Materials Journal, V. 111, No. 1, 1-11, 2014. 